Karsai Gábor

\title{
AZ ISMÉTLÉS
}

(Egy lehetséges ontológiai etika vázlata)

ELőszó

„Nem akarom megítélni, mennyire esnek egybe az én törekvéseim más filozófusok törekvéseivel. Amirôl itt írtam, részleteiben egyáltalában nem lép fel az eredetiség igényével. Ezért nem hivatkozom forrásokra sem, mivel számomra mindegy, vajon azt, amit elgondoltam, gondolta-e már elöttem valaki." - írja Wittgenstein a Tractatus előszavában.

Anélkül, hogy annak alapos és a kétkedóket meggyőzó magyarázatát adnám, úgy vélem, Wittgenstein ezen szavai nem pusztán módszertani megjegyzések, melyeket kiváló gondolkodók szoktak rendszerük elé vetni, hogy olvasóikat félrevezessék.

Ha mégis azok volnának, úgy nekik ezt megbocsátjuk, s mert ószinték voltak, szentté avatjuk óket.

Túl e cinikusnak túnő megjegyzésen, a magam részérôl is hasonló szavakkal élnék. Számomra ugyanis teljesen mindegy, hogy azt, aminek most az elgondolására kísérletet teszek, gondolta-e már elóttem valaki.

Gondolataimat a felejtés eredendősége alapozza meg módszertanilag.

Nem tagadása ez a filozófiatörténet klasszikus és kevésbé klasszikus alakjainak, nem szembehelyezkedés, éppen a hivatkozások hiánya miatt nem az.

Ami itt elgondolásra kerül, akkor éri el a célját, ha legalább egy emberre nézve érvényességgel bír.

Eredendővé pedig csak akkor válhat, ha mindez legalább annak elgondolóját jelenti úgy, ahogy az élni kíván.

Gondolataim csak annyiban érthetőek, amennyiben engem értenek. Engem pedig csak annyiban értenek, amennyiben önmagukat értik.

Nem elfogadásra vágyom, hanem megértésre. Valaminek a megértése ugyanis nem jelenti annak szükségképpeni elfogadását is. A megértés a személynek szól, az elfogadás a rendszernek.

Kívánom tehát, hogy megértsenek. Kívánom, de nem várom el. Elvárásaim csak önmagammal szemben lehetnek. Többre nincs jogosultságom.

Jelen írásom egy több éve tartó gondolkodói folyamat eddigi eredményeinek meglehetősen vázlatos, $s$ a részletes kifejtést mellóző egyfajta összefoglalása kíván lenni, amennyiben az töredékessége és éretlensége miatt egyáltalában rendszerszerü képződménnyé gyúrható.

Gondolkodásom mögött az a fajta késztetés áll, amely az annak való megfelelés által minősít erkölcsi lénnyé, $s$ amely megfelelés a filozófiai értelemben vett élet alapja. 
A rendszer végkövetkeztetésében megszünteti önmagát, s visszajuttat a kezdethez, hogy újra megjárjuk utunkat.

A rendszer: filozófia. Gondolati építmény. Tanulható, ismertethetô, bizonyítható, cáfolható.

Végkövetkeztetésében azonban etikai, s mint ilyen szünteti meg önmagát, hogy alapja lehessen valami magasabbrendúnek, mint a gondolkodás.

Az így megszüntetett rendszer végkövetkeztetése ugyanis nem filozófia, hanem az élet maga, s mint ilyen, túl van minden spekuláción.

Itt azonban nem jutunk el addig. Célunk mindössze ennek a kifutásnak az elökészítése lehet, amelyról tudjuk, hogy eszköz csupán, az eredményt tekintve,hogy nincs eredmény - még az sem igazán.

Mint minden előszó, ez is érthetetlen a "rendszer" nélkül, amely elé írták. Nem baj. $\mathrm{Az}$ igazolásról lemondunk. $\mathrm{S}$ mert lemondunk róla, tû́nhet mindez a legszemérmetlenebb spekulációnak.

\section{AZ ONTOLÓGIAI ETIKA ESZMÉJE}

A filozófiának, amennyiben elveit, s magát a rendszert is az életből százmaztatja, etikának kell lennie. A filozófia etika. (Itt még nem vállalkozhatunk arra, hogy megadjuk, mit is értünk etikán, fogalmát maga az elörehaladó vizsgálódás bontja majd ki.)

Alapelveként a létezés eredendőségét fogjuk megadni, amely nem.más, mint maga az élet.

Az ontológiai etika eszméjének szúk és vázlatos tárgyalásakor, amely a jelen esetben még a kívántnál is szúkebbre szabott, visszafelé kell haladnunk a már elözetesen látott és elgondolt rendszer végkövetkeztetése felól.

Ez a végkövetkeztetés az erkölcsi lény (a minden pillanatban a kellésnek élő valaki) kategóriáján keresztül jelenik meg, s amely közelebbrôl az "azt tenni, amit tenni kell" elvét jelenti, mégpedig a hogyan eredendőségéből eredeztetve.

Az ilyen módon feltárt elv (a kellés elve) az annak való szüntelen megfelelés által hozza életbe annak megcselekvójét.

$\mathrm{Az}$ eredendőség kifejtése, és mindennek egy egységes komplexitásban való szemlélése az egymásrautaló kérdések sorát tárja fel, amelyekre megkísérelünk majd választ adni.

Az etika végső soron egyetlen kategóriából származtatia önmagát, ez pedig a létezés.

A létezésbôl az eredendőség kifejtésével, és a kapcsolódó komplexitás tárgyalásával jutunk el az etika csúcspontjához, az életet annak komolyságában éló erkölcsi lény és a számára elvként megfogalmazódó kellés kategóriáihoz. Ez lesz az etika tárgyalásának és fogalma kibontásának útja.

Mindez azonban igazi alap nélkül maradna, ha a létezést, mint amiból az egész etikai váz kibomlik, nem helyeznénk el a neki alapul szolgáló kategótiák rendszerében. 
Ezt a hiányosságot látjuk egy lehetséges ontológia ketetében megadni, a valamit emelve annak középpontjába.

Igyekszünk majd rámutatni, hogy ontológiánkat új alapokra kell helyezni, kizárva belóle mindazt, amit a logika formalitása csempészne bele a negáció múveletén keresztül.

Törekvésünk ebben a vonatkozásban az ontológia megtisztítása a formális logika negációjától, s ezen keresztül az igaz-hamis értékkettősség eszméjétől.

Úgy túnik azonban, hogy ontológiánkat mégis logikailag kell megalapoznunk, egy olyan logika által, amely viszont alapjaiban csak egy ontológiai preszuppozíció által volna kifejthetô, nélkülözve minden léttagadást.

Bevallom, hogy az ontológiát illető vizsgálódásaim a kezdettől fogva megrekedni látszottak, amint a nemlét, $s$ a nincs kategóriái befurakodtak gondolataim „eresztékei" közé.

Ezen a ponton csak a legutóbbi idókben sikerült valamilyen formában túllépnem, de nem állítom, hogy ez lesz a megoldás, annál is inkább, mert a negációt alkalmazó logika helyébe még nem sikerült valami mást állítani, hacsak a valami teljes egységének tartalmi eszméje nem szolgál akként.

Mindebból látszik, hogy a legnagyobb kérdésekben meglehetősen ingatag és bizonytalan az a gondolati építmény, amelynek elgondolására az elmúlt idókben kísérletet tettem, s hogy az út, amelyre ráléptem, akadályokkal és küzdelmekkel teli, s korántsem biztos, hogy a cél reményével kecsegtet, nem is szólva annak valóságáról.

\section{A VALAMI TELJES EGYSÉGE, S AZ AZT KONSTITUÁLÓ MOZZANATOK}

Ontológiai vizsgálódásunk középpontjában a következó táblázat áll:

\section{VALAMI}

$\begin{array}{ll}\text { LÉT } & \text { LÉTEZÉS } \\ \text { lenni } & \text { létezni } \\ \text { van } & \text { létezik } \\ \text { való } & \text { létezó } \\ \text { valóság } & \text { létezôség }\end{array}$

$$
\begin{aligned}
& \text { VÁL(TOZ)ÁS } \\
& \text { vál(toz)ni } \\
& \text { vál(toz)ik } \\
& \text { vál(toz)ó } \\
& \text { vál(toz)óság }
\end{aligned}
$$

Ontológiánkat egyértelmúen az annak, $s$ így minden másnak is alapul szolgáló kategória, a valami határozza meg.

A valami teljes egységét ontológiailag három, egymást minduntalan átjáró kategória mint annak szerves mozzanatai képezik.

A létezőség vizsgálata a valami teljes egységének csak egyik aspektusát tárná fel, figyelmen kívül hagyva a lét és vál(toz)ás mozzanatait.

A valami tehát lét, létezés és vál(toz)ás szerves, s mint ilyen teljes egységét jelenti ontológiailag.

A valami ezek alapján mint való, mint létező, s mint vál(toz)ó vizsgálandó. 
Különbséget teszünk tehát lét és létezés között. A lét a valami passzív, míg a létezés ugyanezen valami aktív meghatározottságát jelenti. Mindezek bővebb kifejtését a maguk helyén eszközöljük.

Szólnunk kell még a vál(toz)ás kategóriájától is, amelyet szintén a maga helyén fogunk érdemben tárgyalni.

Itt most csak annyit látszik szükségesnek elmondani, hogy a vál(toz)ás a létezés kategóriáján keresztül megjelenve implikálja az idő kategóriáát, amely pedig a voltaképpen̉i etikát teszi lehetôvé lényegi struktúrája, a pillanat, $s$ azon keresztül az ismétlés kategóriája által.

Mindezek után tekintsük a fent vázoltak mélyrehatóbb, bár e keretek között még mindig meglehetősen elnagyolt, $s$ további vizsgálódásokra ösztönző tárgyalását.

\section{A LÉT MINT A VALAMI PASSZÍV MEGHATÁROZOTTSÁGA}

A lét ontológiailag azt jelenti, hogy valami van, s mint ilyen, a róla tett kijelentéseink voltaképpen csak tautológiák lehetnek, azok minden tartalmatlanságával együtt.

Mindezen túl azonban megpróbáljuk közelebbrốl meghatározni a lét ontológiai értelmét.

A lét tehát azt jelenti, hogy valami van. A lét: meglét.

A létnek nincsenek módjai, nem beszélhetünk létmódokról. A létnek nincs foka. A lét, hogy valami van, ebben az értelemben egy, változatlan, örök és teljes.

Valami nem lehet kevésbé, mint valami más. A létnek tehát egyetlen módja van, $s$ ez maga a lét mint meglét. (Módjai a létezésnek vannak.)

A lét ezek alapján a valami passzív meghatározottsága, valami csak annyiban lehetséges, amennyiben van.

A lét azért passzív, mert nem fejez ki semmiféle cselekvést, megnyilvánulást, létezést, mozgást, hanem mindennek alapul szolgál.

A lét állítása csak konstatálás, megállapítás, amely emiatt mentes minden értékítélettól (igaz-hamis), etikaitól, morálistól, tartalomtól.

A lét nem azonos továbbá az élet fogalmával sem, amely utóbbi etikai kategória, $s$ a létezés különböző lehetséges modifikációinak egyike.

\section{KIEGÉSZÍTÉS:}

Lét: valami van. Mit jelent a "van"? Logikai kopula-e, avagy meglétet jelöl? Íme két kijelentés:

Az alma piros.

(itt színt, azaz tulajdonságot állítunk róla)
Az alma pirosként meglévő.

(itt létet állítunk róla)

Vajon a tulajdonság állítása nem csak a lét állításával egyidejúleg lehetséges?

Az alma piros. - Az alma a piros színnel bír. Ha a „van" átírható a "bír" formájára, akkor ott kopulaként szerepel. 
Az alma nem piros. - Nem igaz, hogy az alma piros - mondja a logika. Az alma nem bír a piros színnel.

A logikai negáció mindaddig áll, amíg az nem a létre vonatkozik, s nem létet negál.

$\mathrm{Az}$ alma nincs. $\mathrm{E}_{2}$ a mondat teljességgel érthetetlen.

Míg ugyanis a fenti esetekben a logikai negációnak alapul szolgált az, hogy az alma van, ez utóbbi esetben éppen ennek negálásáról van szó.

Ám a kijelentéseknek, s így a logikai negációnak is mindig valamiféle lét szolgál alapul, így a „nemlét” állításakor szükségképpen ellentmondást tapasztalunk, hiszen a nemlét állításának is alapul kell, hogy szolgáljon annak előzetes léte, amelynek éppen tagadni kívánjuk a létét.

Lét pedig nem szolgálhat alapul nemlétnek, a nemlét teljesen megalapozatlan kategória, s a negáció jogosulatlan kiterjesztésén alapul.

'Az alma nincs' kijelentés átírható 'Az alma nem bír léttel' kijelentéssé, mondhatnánk, $s$ ebben az esetben a logikát érintő megjegyzéseink csődöt mondanának. Itt a bír-formáta való átírás miatt a „van" (nem van) kopulatív használatú volna. Ám jól látható az ilyen érvelés hibája.

'A z alma nem bír léttel' kijelentésben az alma valami olyasmi, ami nem bír léttel, de mint ilyen, ahhoz, hogy egyáltalán mondhassuk, hogy a valami nem bír valamivel, a bír alapjául annak létét állítjuk, még akkor is, ha a bír igét tagadjuk.

A lét azonban nem tagadható, $s$ a létet tagadó logikai állítás ilyen módon logikailag fog ellentmondást felmutatni.

A léttagadás értelmetlenség, mert ahhoz, hogy tagadhassuk valaminek a létét, éppenhogy feltesszük és állítjuk azt, amit tagadni kívánunk.

Gondolkodásunk használatának ilyen módon a lét határt szab, azon belül azonban továbbra is fennállnak formai következtetései.

A létről tehát formállogikailag nem mondhatunk többet a tautológiánál. A létről szóló bármiféle kijelentés ilyen módon logikán kívüli.

Mindezek az észrevételek csak a probléma felvetését szolgálták, a bizonyítást, s a továbbgondolást egy későbbi, mélyebb és alaposabb kifejtésre utalva.

Mindazonáltal, ahogy azt a bevezetôben jeleztük, az is meglehetősen bizonytalan a számunkra, hogy vajon tényleg ez-e az ontológia jelzett problémája megoldásának útja.

\section{A LÉTEZÉS MINT A VALAMI AKTÍV MEGHATÁROZOTTSÁGA}

A létezés a valami aktív meghatározottsága, amennyiben a létezés megnyilvánulás, amelyben a lét kinyilvánítása folyik, miáltal a létezés viszonyulás, mozgás is.

Létezés csak lét által lehetséges, ám annyiban szükségszerú is.

A létezés: megnyilvánulás, amelyben a lét kinyilvánítása folyik, s mint ilyen, csak általa szerzünk tudomást valaminek a létéról.

A létet tehát a létezés nyilvánítja $k i$, a lét ennek megfelelően nem más, mint a megnyilvánulásban kinyilvánított, a létezés pedig maga a megnyilvánulás mint kinyilvánító. 
A létezés mint megnyilvánulás maga az egyszeri pillanatban tételeződó aktus, a megnyilvánulás mint folyamat, ahogy valami a zártság állapotából kinyílva nyitottságra jön.

A létezés a fogalmában tételezôdő megnyilvánulás mint a zártságból a nyitottságra jövés által foglalja magában a mozgást, amely maga ez a pillanatban tételeződő nyitottságra jövés a lét kinyilvánítása szerint.

\section{A VÁL(TOZ)ÁS MINT AZ IDŐ TÉTEZŐDÉSE}

A vál(toz)ás nem más mint a létezésről mondottak időbeli kivetülése.

A létezés az egyszeri pillanatban tételeződött mozgásként, mégpedig a lét kinyilvánítása által, ahogy a valami a zártságból nyitottságra jön.

A vál(toz)ás ennek a nyitottságra jövésnek minden idópillanatban való tételezôdése.

A pillanat fogalmát, s ebben az idővel való összefüggését az etikai tárgyalásakor adjuk, mint amely miatt egyáltalán etika lehetséges.

\section{AZ ETIKAI KIBOMLÁSA A LÉTEZÉS, S A VÁL(TOZ)ÁS EDDIGI FOGALMA ALAPJÁN}

(A létezés mint élet. $\mathrm{Az}$ ismétlés. A valaki.)

Létezésem létemhez való viszonyulásom, a megnyivánulás mint mozgás létkinyilvánítását a hogyanban tételezve.

Létezésem azonnali viszonyulás létemhez az egyszeri időpillanatban, mégpedig a nyitottságra jövés folyamatában.

A létkinyilvánítás ugyanis történik.

Létemhez való viszonyulásom e létkinyilvánítás hogyanja. Ez az etikai tételezôdésének mozzanata, mégpedig az így kibomlott hogyan eredendősége által.

Létemhez való etikai viszonyulásom a hogryan eredendősége által létezésem etedendősége.

Létezésem eredendósége pedig maga az élet. Az élet tehát a létezés egy módja, amennyiben az eredendó.

Ennek alapja az ismétlés.

\section{AZ ISMÉTLÉS}

Ismétlés csak a pillanatban lehetséges. Ismétlés csak annyiban van, amennyiben az idö pillanatnyi.

Létem az idő szerkezetén alapszik. A pillanat nem azonos a mosttal. Az idô nem pontok sorozata.

$A z$ idő egységes. $A z$ idő az én idôm. $A z$ idő létem ideje. ( $E_{z}$ nem azonos azzal az idővel, amit születésemtől halálomig „élek”.)

Én magam is pillanatnyi vagyok. A pillanat maga az idô. Az élet mindig a pillanat, a pillanat pedig mindig az első, $s$ az utolsó is egyben.

A pillanat az idő. Ismétlés csak emiatt lehetséges. Ismétlés csak emiatt szüksẻges.

$A z$ ismétlést nem én végzem. 
$\mathrm{A} z$ ismétlés maga a pillanat, amely velem történik, amelyben történek. Történetiség csak ennyiben van. A történetiség, hogy történek, csak a pillanatban érthetoo.

Nincs jövő, múlt s jelen. A pillanatban állandóan a végnél vagyok. Maga ez a vég vagyok. A vég egyben kezdet is.

Énem igazsága a pillanat. Eredendősége az ismétlés.

Ismétlés: az élet maga. A történés szabadságában. Azt tenni, amit tenni kell.

$\mathrm{E} z$ a választás lehetetlensége. Választás a pillanatban az ismétlés által.

$\mathrm{Az}$ igazi választás a választás függetlensége attól, aki választ. Egyszersmind a választás lehetetlensége.

Azt tenni, amit tenni lehet így ugyanaz, mint amit tenni kell. Választásom független tôlem, az akaratomtól.

$\mathrm{Az}$ akarat csak annak fontos, aki fél, s így magát akarja, mert félti magát.

Mondani csak ugyanazt lehet. Aki cáfol, az nem ért. Aki ért, az hallgat. A hamisságot nem cáfolni kell, hanem ellenemondani az igazságot vagy hallgatni. Aki csak a cáfolattal él, maga is hamis.

$\mathrm{A} z$ igazság mondása voltaképpen hallgatás. A tartalom nem a szavakban van, hanem az életben. Aki él, szavak nélkül él.

A pillanat kor, történelem és hely nélkül való. $A z$ ismétlés a pillanat ismétlése. Aki él, csak ismételni tud. Az életet ismétli. A pillanatot ismétli.

$\mathrm{Az}$ ismétlés nem ugyanannak a megtételében áll, hanem a pillanatnak való megfelelésben. Aki a pillanatnak megfelel, ismétel.

Nem én teremtem a pillanatot, $s$ ami abban van. A pillanat teremt engem. A pillanat csak annyiban teremthet engem, amennyiben vagyok.

A pillanat létemből fakad, az idő létem által lehetséges, létezés pedig az idő által.

A létezés ismétlés. Lét és létezés olyan viszonyban áll egymással, mint pillanat és ismétlés.

$\mathrm{Az}$ ismétlésben nincs új, $\mathrm{s}$ nincs régi. $\mathrm{A} z$ ismétlés nem ismer elavultat, $\mathrm{s}$ újdonságot sem.

$\mathrm{A} z$ ismétlésben minden örök, minden ismert, de nem a tudott szintjén, hanem a megélésben. $\mathrm{Az}$ ismétlés ez.

Mindig eredendőnek kell lenni. Az eredendóség pillanatnyi. Csak a pillanatban lehetséges. lenni.

Mindig eredendőnek lenni így azt jelenti, minden pillanatban eredendőnek

Ez a vál(toz)ás eredendősége.

$\mathrm{A} z$ ismétlés az eredendóségre vonatkozik. Ismételni az eredendóséget.

$\mathrm{A} z$ eredendőség nem az enyém. Az eredendőség a létezésből fakad. A viszonyból létemhez. Létezés: viszony saját létemhez. Létezés: megnyilvánulás. Eredendő létezés: ismétlés.

$\mathrm{Az}$ eredendőség így a létemhez való eredendố viszonyulásban áll.

A létemhez való eredendố viszonyulás annak belátása, hogy vagyok, miáltal létezni vagyok rendelve. 
A létemhez való eredendlő viszonyulás mint ismétlés így ennek minden pillanatban történő belátása, amely a vál(toz)ás eredendősége.

A belátás pedig nem más, mint az annak való megfelelés, amely a pillanatban mindig adott a számomra.

A pillanatban adottnak való megfelelés annak elfogadása, amely számomra a pillanatban kijelöltetett.

A kijelölt lehetôségek szabad elfogadása az annak való megfelelés által végső soron annak belátása, hogy létemmel szemben soha nem lehet igazam, létemből eredendóen következik létezésem, amely által, ha az ezen a belátáson nyugszik, az abban tételezett viszonyulást létemhez rendelem, s abból alapozom meg.

Ez végső soron a pillanatban adott lehetőségeknek való megfelelésre fut ki etikailag, annak minden pillanatban való megtétele, azaz ismétlése által.

Mindezt a kellés (azt tenni, amit tenni kell) fogja össze.

A kellésnek való megfelelés a létemből eredố lehetőségek szabad áramlása elötti akadályok visszavonásán alapul.

$\mathrm{Ez}$ a visszavonás pedig nem más, mint eloldódás a dolgok (lehetôségek) felett gyakorolt uralmamtól, szabad teret biztosítva létem eredendőségének. Az ismétlés tárgya voltaképpen ez az eloldódás.

Az eloldódás bezáródás önmagamba. Éppen ez a bezáródás biztosítja azonban a pillanatban adottra való szabad és korlátlan kinyilást.

$\mathrm{S}$ az, aki mindezt ebben a formában éli, a valami ontológiai státuszából a valaki etikai pozíciójába lép elő.

A valaki tehát a létéhez eredendően viszonyuló, azt minden pillanatban az ismétlés által megélố erkölcsi lény, aki a kellésnek megfelelóen e viszonyulásban mindig azt cselekszi, amit cselekednie kell.

Ez a hogyan eredendősége, s a mi is csak ezáltal lesz etikaivá.

A rendszer végkövetkeztetése ez. S miután nem tartalmaz egyetlen paragrafusokba szedett erkölcsi normát sem, az életre éppoly kevés használható információval bír, mint elgondolása elött.

Miridezt ténylegesen csak maga az élet igazolhatja.

\section{AZ ISMÉTLÉS}

( $\mathrm{A} z$ ismétlés egy lehetséges újragondolásának kísérlete)

$\mathrm{Az}$ ismétlés a létezés eredendô módjának, az életnek ontológiai alapja, amenynyiben az ismétlés voltaképpeni tartalma a hogyan eredendôsége.

A hogyan a létkinyilvánítás hogyanja.

A létkinyilvánítás létemhez való viszonyulásom.

Amennyiben ez a viszony etikai, a viszonyulás eredendőségéról beszélünk.

$\mathrm{A} z$ etikai viszonyulást nevezzük a létezés eredendőségének.

Minden viszonyulás azonban e viszonyulás hogyanja által minősíthetố csak, az etika zsinórmértéke szerint.

Mi az a tartalom, amely szerint az etikai hogyan mint a hogyan eredendösége megadható? 

ben.

Ezt véljụ̈ a kellésben megadni, az „azt tenni, amit tenni kell” kényszerítésé-

Mit jelent az, hogy az idő pillanatnyi?

A pillanat érthetetlen a vál(toz)ás nélkül. idő?

Ha a vál(toz)ás az idő tételezódése, akkor miként lehet az, hogy a pillanat az

Az idő nem pontok sorozata, hanem vál(toz)ások egysége.

Mit jelent akkor a pillanatnyi idő?

A pillanat az idö- mondom.

A vál(toz)ás is csak a pillanatban tételeződhet?

Vagyis a vál(toz)ásnak alapul szolgál az, hogy az idő pillanatnyi?

De akkor miként lehet az, hogy az időt a vál(toz)ás tételezi?

$\mathrm{Az}$ eredendő idő a pillanat volna?

De akkor mi a vál(toz)ás nyomán tételeződő idő?

Ismétlés annyiban van, amennyiben az idő pillanatnyisága a vál(toz)ạ́sok egységében újra meg újra megvalósul.

Az ismétlés tehát az idő pillanatnyiságára vonatkozik.

De ez egy folyás.

A vál(toz)ások egysége a folyás.

$A z$ idố csak ebben tételeződhet.

A vál(toz)ások egységében mint folyásban tételezôdő idő eredendősége a pillanatnyiság.

Az ismétlés a pillanat ismétlése.

$\mathrm{S}$ mivel az ismétlésben a hogyan ismétlése zajlik, a pillanat ismétlése a hogyan ismétlése minden pillanatban.

A hogyan eredendőségének fenntartása a vál(toz)ások egységeként konstituálódó folyásban, ez az ismétlés.

A vál(toz)ás tehát a valami azon konstitutívuma, amely miatt egyáltalán etikai lehetséges.

Ennyiben a viszonyulás igazi hordozója, amely nélkül a létezés egyszeri viszonyulása mint elrendeltség volna csak értelmezhető.

A viszonyulás igazi hordozójaként a vál(toz)ás az, ami lehetővé teszi a szabadságot, a szabad viszonyulást etikai zsinórmérték tárgyává téve az eredendőség tartalmán keresztül.

A vál(toz)ások egységében mint eredendő folyásban tételeződő idó eredendősége a pillanatnyiság.

Az eredendő idő a pillanat.

A vál(toz)ás eredendósége a vál(toz)ások egységének pillanattá válása.

A vál(toz)ások egységének mint folyásnak eredendósége az egység eredendősége.

Az egység eredendősége az egység pillanattá válása.

Hogyan lesz az egység pillanattá?

$\mathrm{Az}$ ismétlés által.

Az ismétlésben tételezett, a megismételt által. 
